\title{
Effect of Peristrophe bicalyculata powder on diabetic and lipid parameters in the stomach of albino rats
}

\begin{abstract}
To determine the effect of Peristrophe bicalyculata Powder on diabetic and lipid parameters in Stomach of rats. Twenty-five rats were divided in five groups of five animals per group: group fed with normal chow and distilled water and groups treated with Peristrophe bicalyculata at a concentrations of $5 \mathrm{~g}, 10 \mathrm{~g}, 15 \mathrm{~g}$ and $20 \mathrm{~g}$ respectively. At the end of the 21 day, the animals were sacrificed and blood sample were collected for biochemical and histological analysis. Diabetics were assessed in stomach by measuring the levels of selected blood parameters of glucose, cholesterol, triglycerides, insulin and protein and the effect of histopathology. Treatment with Peristrophe bicalyculata reduced the stomach weight of animals and reduced significantly $(\mathrm{p}<0.05)$ levels of glucose, insulin, protein, cholesterol and triglycerides. Data were expressed as mean \pm standard deviation (SD) and were analyzed by the analysis of variance (ANOVA). The difference between the various concentrations and animal groups were compared using the Duncan Multiple Range Test. P value less than 0.05 was considered significant $(\mathrm{P}<0.05)$.
\end{abstract}

Keywords: Peristrophe bicalyculata, diabetes mellitus, gastrointestinal disorders, biochemical and histological analysis.
Volume 3 Issue 4 - 2018

Sheneni Victor Duniya, Shaibu Isaac Eleojo, Jegede Rapheal Eneji, Omede Ameh,Abaniwo Rose Mafo, Mamudu Ojonugwa Collins

Department of Biochemistry, Kogi State University, Nigeria

Correspondence: Sheneni Victor Duniya, Department of Biochemistry, Faculty of Natural Sciences, Kogi State University, PMB 1008,Anyigba, Nigeria, Tel +234- 8033519009, Email shenenivictor@gmail.com

Received: July 10, 2018 | Published: July 26, 2018

\section{Introduction}

Peristrophe bicalyculata is a herbaceous plants which belongs to the family Acanthaceae. The Hausas call it tubanin dawaki in Nigeria, which means horse flour. In Senegal the serer and Wolof language call it buben and moto. ${ }^{1}$ It is called chotiharjori ${ }^{2}$ by the Indore zone of the Indians. Naturally it is found in the warm tropical areas of Africa, in the sahel area of Mauritania, northern part of Nigeria and also in Thailand, India and Burma. The plant is used locally in the treatment of diabetes in the south western part of Nigeria. The plant is a stimulant, stomachic and a diuretic. Chewing the plant leaves suppresses the sweet and bitter in it. The consumers of this usually expects a reducing effect on weight and betterment of diabetes due to its ability to reduce taste of sweet and prevent the absorption of glucose by the cells. Diabetes mellitus is a metabolic disorder characterized by elevated blood sugar level, abnormalities in lipoprotein metabolism and intermediary embolism of major food substances. ${ }^{3}$ Rare cases of hepatic inflammation induced by anthraquinone have been documented, ${ }^{4}$ and are dose depended. Anthrax quinines are metabolised in the small intestines, forming hepatic toxic substances that some people are sensitive to. This substances result to reversible liver abnormality. Gastrointestinal disorder is one of the prevailing reasons why people seek medical advice. About approximately 15$30 \%$ of full grown adults suffer from this condition. The discovery of functional drugs is one of the major areas of phototherapeutic treatment today. From the day immemorial, bitter herbal drugs from neem or vernonia amyygdalina has been implicated in the treatment of patients with dyspeptic complaint. The mechanism of action of how this bitter herb elicits their biological function is not fully understood. But it is believed stimulate the stomach secretion, digestive glands and strengthens gastrointestinal tract thus stimulating the CNS, leading to notification. Bitters, especially at a very high dose affect positively the mucous membrane lining of the stomach and bowel. They are usually combined with essential oil, which are known for their spasmolytic, aesthetic and carminative effect. ${ }^{5}$ This study shows the effect of various concentrations of Peristrophe bicalyculata in albino rats.

\section{Methodology}

\section{Collection of plant material and identification}

The Peristrophe bicalyculata plants were collected from its natural habitat at the Institute of Agricultural Research (IAR), Ahmadu Bello University (ABU), Zaria, Kaduna State in the month of April 2017, and authenticated at the Herbarium unit by Gallah U.J in the Department of Biological Sciences, Ahmadu Bello University, Zaria with a voucher number 1002. The specimen was dried at room temperature and blended into powder.

\section{Animals}

Healthy Wister albino rats of both sexes weighing between 100 $-150 \mathrm{~g}$ were obtained from National Institute for Trypanosomiasis Research, Kaduna, Nigeria, and kept according to sexes in well aerated laboratory cages in the Animal house, Department of Pharmacology, Ahmadu Bello University, Zaria, Nigeria. The animals were allowed to acclimatize to the laboratory environment for a period of two weeks before the commencement of the experiment. They were fed with water and grower mash ad labium.

\section{Animal grouping}

A total of 25 rats were used. The rats were randomly divided into 5 groups of 5 rats each.

1. Control Group I: were fed with normal chow and distilled water only for 21 days.

2. Treatment Group II: were given 5g of Peristrophe bicalyculata powder with normal chow and distilled water only for 21 days.

3. Treatment Group III: were given $10 \mathrm{~g}$ of Peristrophe bicalyculata powder with normal chow and distilled water only for 21 days.

4. Treatment Group IV: were given $15 \mathrm{~g}$ of Peristrophe bicalyculata powder with normal chow and distilled water only for 21 days. 
5. Treatment Group V: were given $20 \mathrm{~g}$ of Peristrophe bicalyculata powder with normal chow and distilled water only for 21 days.

The animals were made to fast for a night after the treatment period. They were sacrificed by cardiac puncture using chloroform vapor, and the blood samples were collected using EDTA bottles. The collected bloods were centrifuged to recover the plasma using a centrifuge machine at a speed $5000 \mathrm{rpm}$ for 15 minutes. The stomach were removed and weighed immediately and then taken for histopathological analysis. The different weights of the stomach from the different groups were taken.

\section{Biochemical parameters}

Glucose estimation: The blood glucose level were determined based on glucose oxidase/peroxides principle, described by Clark \& Lyons, ${ }^{6}$ using Accu-Chek Advantage II digital glucometer.

Protein estimation: Total proteins were determined calorimetrically according to the method described by Fine ${ }^{7}$ using Randox assay kits.

Cholesterol estimation: The serum level of cholesterol were quantified by method described by Stein, ${ }^{8}$ using assay kits (Randox Laboratories Ltd).

Triglyceride estimation: The serum triglyceride levels were determined by enzymatic method described Stein, ${ }^{8}$ using Randox assay kits.

Insulin estimation: The insulin levels were measured by solid phase enzyme linked immune sorbent assay (ELISA).

Histopathological analysis: The weighed stomachs were stored in 15 $\%$ formalin. The stomach was stained with hematoxylin and eosin, the stained portion was carefully observed using microscope to evaluate the extent of diabetes.

\section{Data analysis}

Data are expressed as mean \pm standard deviation (SD) and were analyzed by the analysis of variance (ANOVA). The difference between the various concentrations and animal groups were compared using the Duncan Multiple Range Test. $P$ value less than 0.05 was considered significant $(P<0.05)$.

\section{Results}

\section{Biochemical parameters:}

The studies reveal that animals fed with Peristrophe bicalyculata in treatment group II showed a significant $(\mathrm{p}<0.05)$ decrease in body weight of the rats from $180.0 \pm 16.4$ to $158.0 \pm 11.0 \mathrm{gm}$. The same also with animals fed with powder in treatment groups III, IV and V showed a significant $(\mathrm{p}<0.05)$ decrease when compared to the previous day at the end of the 21 day (Table 1). In treatment group II there was a slight increase in mean insulin concentration level $(0.22 \pm 0.06)$ when compared to treatment group I and III. Treatment group IV and V showed a significant $(\mathrm{p}<0.05)$ decrease in mean insulin concentration level when compared with treatment group I, II and III. Peristrophe bicalyculata significantly affects plasma insulin levels of normal animals at high concentration, treatment group IV and $\mathrm{V}$ respectively (Table 2). The mean blood glucose levels showed normal value of $90.40 \pm 4.4,88.16 \pm 2.8$ and $85.08 \pm 4.3$ in the treatment groups I, II and III respectively. At high concentration, the mean blood glucose levels decreased steadily, treatment group IV and V (Table 3).
Table I Body weight of albino rats treated with Peristrophe bicalyculata

\begin{tabular}{llll}
\hline \multicolumn{4}{l}{ Mean body weight \pm S.D(gms) } \\
\hline $\begin{array}{l}\text { Treatment } \\
\text { groups }\end{array}$ & Initial weight & Final weight & $\begin{array}{l}\text { Percent } \\
\text { change }\end{array}$ \\
II & $180 \pm 16.4$ & $158 \pm 11.0$ & -22 \\
III & $126.4 \pm 23.5$ & $103.8 \pm 22.2$ & -22 \\
IV & $198.0 \pm 19.8$ & $145.4 \pm 36.1$ & -52 \\
V & $175.0 \pm 36.3$ & $130.9 \pm 21.9$ & -44 \\
\hline
\end{tabular}

Table 2 Plasma insulin level of albino rat treated with Peristrophe bicalyculata

\begin{tabular}{|c|c|c|c|c|c|c|}
\hline \multirow[t]{3}{*}{$\begin{array}{l}\text { Treatment } \\
\text { groups }\end{array}$} & \multicolumn{5}{|c|}{ Insulin $\mu \mathrm{I} / \mathrm{ml}$} & \multirow[t]{3}{*}{ Mean \pm SD } \\
\hline & \multicolumn{5}{|c|}{ Number of rats } & \\
\hline & I & 2 & 3 & 4 & 5 & \\
\hline I & 0.13 & 0.12 & 0.14 & 0.18 & 0.13 & $0.14 \pm 0.02$ \\
\hline II & 0.14 & 0.22 & 0.3 & 0.2 & 0.24 & $0.22 \pm 0.06$ \\
\hline III & 0.15 & 0.16 & 0.12 & 0.1 & 0.16 & $0.13 \pm 0.02$ \\
\hline IV & 0.06 & 0.06 & 0.07 & 0.07 & 0.08 & $0.06 \pm 0.01$ \\
\hline V & 0.02 & 0.02 & 0.04 & 0.04 & 0.05 & $0.03 \pm 0.01$ \\
\hline
\end{tabular}

Table 3 Plasma glucose level of albino rat treated with Peristrophe bicalyculata

\begin{tabular}{|c|c|c|c|c|c|c|}
\hline \multirow[t]{3}{*}{$\begin{array}{l}\text { Treatment } \\
\text { groups }\end{array}$} & \multicolumn{5}{|c|}{$\begin{array}{l}\text { Concentration } \\
\text { of glucose } \\
(\mathrm{mg} / \mathrm{dl})\end{array}$} & Mean \pm SD \\
\hline & \multicolumn{5}{|c|}{$\begin{array}{l}\text { Number of } \\
\text { rats }\end{array}$} & \\
\hline & I & 2 & 3 & 4 & 5 & \\
\hline I & 82.40 & 94.7 & 92.12 & 89.70 & 91.70 & $90.40 \pm 4.4$ \\
\hline II & 84.41 & 86.12 & 93.27 & 84.27 & 92.73 & $88.16 \pm 2.8$ \\
\hline III & 80.2 & 81.00 & 89.39 & 87.12 & 87.7I & $85.08 \pm 4.3$ \\
\hline IV & 70.14 & 75.13 & 66.95 & 77.21 & 77.45 & $73.37 \pm 2.2$ \\
\hline V & 47.55 & 51.75 & 56.30 & 57.30 & 49.96 & $53.66 \pm 3.8$ \\
\hline
\end{tabular}

The treatment group I, II and III produced no significant $(\mathrm{P}>0.05)$ reduction in plasma protein level. But treatment group IV and V showed a significant $(\mathrm{p}<0.05)$ increase when compared to other treatment groups. Peristrophe bicalyculata show no significant $(\mathrm{P}>0.05)$ difference in the plasma protein concentration of normal animals even up to higher concentration groups of treatment (Table 4). The mean triglyceride concentrations showed normal values in treatment group I, II and III. At high concentrations of treatment, group IV and $\mathrm{V}$ values decreased steadily with maximum decrease in treatment group V (Table 5). The mean cholesterol levels in group II and III showed slight difference when compared with group I. There was a significant reduction in mean cholesterol level as the concentration increases in group IV and V (Table 6). The control group I shows no difference from the normal histology of the stomach. The mucosal cells, sub-mucosal layer, gastric pits and epithelial cells were clearly observed. No significant change was observed in treatment group II, III and IV. The rats treated with Peristrophe bicalyculata (treatment group V) showed a clear stomach shrinkage. Although no ulceration was observed (Figure 1). 


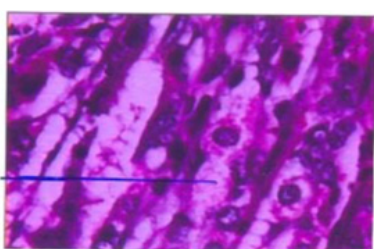

control

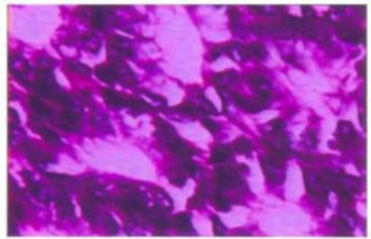

$10 \mathrm{gm}$

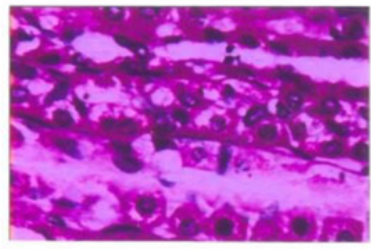

$5 \mathrm{gm}$

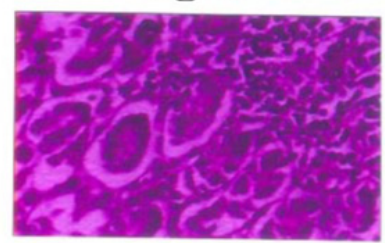

15gm

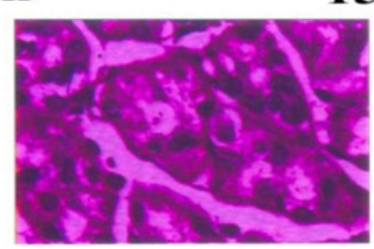

\section{0gm}

Figure I Result of histopathological analysis.

Table 4 Plasma protein level of albino rat treated with Peristrophe bicalyculato

\begin{tabular}{|c|c|c|c|c|c|c|}
\hline \multirow[t]{3}{*}{$\begin{array}{l}\text { Treatment } \\
\text { groups }\end{array}$} & \multicolumn{5}{|c|}{$\begin{array}{l}\text { Concentration of } \\
\text { protein }(\mathrm{mg} / \mathrm{dl})\end{array}$} & \multirow[t]{3}{*}{ Mean \pm SD } \\
\hline & \multicolumn{5}{|c|}{ Number of rats } & \\
\hline & I & 2 & 3 & 4 & 5 & \\
\hline I & 7.6 & 7.5 & 6.9 & 7.9 & 7.5 & $7.52 \pm 0.3$ \\
\hline II & 8.1 & 7.6 & 7.5 & 7.5 & 7.2 & $7.66 \pm 0.2$ \\
\hline III & 8.1 & 8.4 & 8.1 & 8.1 & 8.3 & $7.80 \pm 0.1$ \\
\hline IV & 8.7 & 7.9 & 7.8 & 7.8 & 8.2 & $8.04 \pm 0.3$ \\
\hline V & 8.5 & 8.3 & 8.3 & 8.3 & 8.5 & $8.14 \pm 0.1$ \\
\hline
\end{tabular}

Table 5 Plasma triglyceride level of albino rat treated with Peristrophe bicalyculata

\begin{tabular}{|c|c|c|c|c|c|c|}
\hline \multirow[t]{3}{*}{$\begin{array}{l}\text { Treatment } \\
\text { groups }\end{array}$} & \multicolumn{5}{|c|}{$\begin{array}{l}\text { Concentration } \\
\text { of triglyceride } \\
(\mathrm{mg} / \mathrm{dl})\end{array}$} & Mean $\pm S D$ \\
\hline & \multicolumn{5}{|c|}{ Number of rats } & \\
\hline & I & 2 & 3 & 4 & 5 & \\
\hline I & 52.32 & 58.69 & 48.78 & 54.85 & 48.70 & $55.80 \pm 3.7$ \\
\hline II & 42.32 & 45.13 & 43.73 & 44.74 & 50.65 & $46.59 \pm 2.8$ \\
\hline III & 39.10 & 41.39 & 39.85 & 47.95 & 47.53 & $43.89 \pm 3.8$ \\
\hline IV & 38.18 & 36.72 & 38.91 & 37.29 & 37.49 & $38.64 \pm 0.7$ \\
\hline V & 33.40 & 35.75 & 35.35 & 34.80 & 32.78 & $34.4 I \pm 0.01$ \\
\hline
\end{tabular}

Table 6 Plasma cholesterol level of albino rat treated with Peristrophe bicalyculata

\begin{tabular}{|c|c|c|c|c|c|c|}
\hline \multirow[t]{3}{*}{$\begin{array}{l}\text { Treatment } \\
\text { groups }\end{array}$} & \multicolumn{5}{|c|}{$\begin{array}{l}\text { Concentration } \\
\text { of cholesterol } \\
(\mathrm{mg} / \mathrm{dl})\end{array}$} & Mean $\pm S D$ \\
\hline & \multicolumn{5}{|c|}{ Number of rats } & \\
\hline & I & 2 & 3 & 4 & 5 & \\
\hline I & 91.40 & 80.52 & 87.39 & 89.11 & 91.30 & $88.01 \pm 4.0$ \\
\hline II & 85.74 & 83.59 & 83.25 & 84.37 & 91.30 & $86.01 \pm 2.7$ \\
\hline III & 79.15 & 87.29 & 87.31 & 87.31 & 87.38 & $85.10 \pm 3.2$ \\
\hline IV & 61.01 & 69.21 & 75.29 & 76.51 & 77.56 & $77.31 \pm 6.1$ \\
\hline V & 44.39 & 43.23 & 57.35 & 48.78 & 48.98 & $48.03 \pm 4.2$ \\
\hline
\end{tabular}

\section{Discussion}

There was no mortality in dose up to treatment group $\mathrm{V}$ body weight animals, only changes in behavior was observed. Treatment group II and III of animals fed with Peristrophe bicalyculata showed no change in behavior but treatment group IV and V showed appetite suppression and lethargic movement. The body weight of animals and food intake decreased in a dose depended manner. The decrease in body weights of the animals may most likely be due to the decreased food intake as a result of appetite suppression and faint aromatic smell and tastelessness. ${ }^{9}$ Peristrophe bicalyculata is known to cause suppression of receptors of sweet taste on the tongue. ${ }^{10}$ Similar study also observed a dose depended change in fenugreek seeds. ${ }^{11}$ No mortality was observed in this study, the likely reason could be that Peristrophe bicalyculata did not interfere with the internal organs of these animals and a such did not impose any severe toxicity to the animals that can lead to death. ${ }^{12}$ There was a decreasing level of insulin and glucose with increasing concentration. Insulin is a hypoglycemic drug; a higher concentration will reduce blood glucose level drastically. Insulin main function is reduction of blood glucose level; but since the glucose level is already low due to Peristrophe bicalyculata, the need for insulin becomes highly reduced. This reason could be ascribed for the decreased level of insulin. In the control animal group and low doses of treatment group II and III of Peristrophe bicalyculata, the insulin levels were normal. Peristrophe bicalyculata is known to be insulinotrophic and insulin secretion promoter. ${ }^{13}$

The plasma levels of protein of the animals treated with different concentrations of Peristrophe bicalyculata showed no significant changes, all the administered doses were similar to the normal control animals. Thus the herbal powder of Peristrophe bicalyculata had no effect on the plasma levels of protein on the animals. The likely reason for this decrease could be that the animals are normal, without hyperglycemia or hypercholesterolemia. The animals treated with low doses of Peristrophe bicalyculata showed no significant change in the serum levels of cholesterol and triglycerides. This may be ascribed to the normal diet. ${ }^{14}$ The higher concentrations of treated group IV and V, showed a decrease in cholesterol which may be ascribed to the powder interacting with cholesterol in the intestinal tracts of the animals. The lipid lowering effect is a secondary endpoint in this study, designed to demonstrate the anti-diabetic property of Peristrophe bicalyculata. The four walls of the stomach (mucosa, sub mucosa, muscular is external and serosa) were all intact. The mucosa is embedded in the 
inner layer, and it shows three distinctive portions. The trivial portion contains gastric hallows; the middle portion contains the necks of the glands, this has the tendency or disposition to stain with eosin; and the most deep portion of the mucosa stains blue. The empty stomach (inner surface) is convoluted into long folds called rufae. It consists both of mucosa and sub-mucosa. The reggae are temporary, it disappear when the mucosa of the stomach is stretched as in the case of a dilated stomach. The luminal portion of the stomach has many tiny openings called gastric pits which are formed by epithelial cells that invigilates connective tissues.

\section{Conclusion}

Peristrophe bicalyculata has no serious effect to diabetics at low concentrations. However at higher concentrations, there is a histopathological change. Low dosage of Peristrophe bicalyculata does not affect the protein, insulin, glucose and cholesterol or triglycerides. Peristrophe bicalyculata can thus be recommended at low dosage in various ailments on the advice of a physician.

\section{Acknowledgments}

None.

\section{Conflict of interest}

Author declares there is no conflict of interest.

\section{References}

1. Burkill H. Peristrophe bicalyculata (Retz) Nees [family ACANTHACEAE]. Royal Botanical Gardens. 1995;1.

2. Dwivedi S. Ethno medicinal uses of some plant species by ethnic and rural peoples of Indore district of Madhya Pradesh, India. 2002.

3. Scoppola A, Montecchi FR, Mezinger G, et al. Urinary mevalonate excretion rate in type 2 diabetes, role of metabolic control. Atherosclerosis. $2001 ; 156(2): 357-361$.
4. Nadir A, Reddy D, Van Thiel DH. Cascara sagrada-induced intrahepatic cholestasis causing portal hypertension: case report and review of herbal hepatotoxicity. Am J Gastroenterol. 2000;95(12):3634-3637.

5. Saller R, Iten F, Reichling J. Dyspetic pain and phytotherapy--a review of traditional and modern herbal drugs. Forsh komplementarmed klass naturheild. 2001;8(5):263-273.

6. Clark Jr LC, Lyons C. Electrode systems for continuous monitoring in cardio logical surgery. Ann N Y Acad Sci. 1962;102:29-45.

7. Fine J. The biuret method of estimating albumin and globulin in serum and urine. Biochemical Journal. 1935;29(3):799-803.

8. Stein EA. Lipids, lipoproteins and apolipoprotein metabolism. Fundamentals of Clinical Chemistry. 3rd ed. Philadelphia: WB. Saunders Company; 1987.

9. Deepak Archarya, Anshu Shrivastava, Garima Sancheti. Introduction Gymnema sylvestre-Boosts your insulin. Drug Information Journal. 2006;34:801-808.

10. Marquet F, Abou EI, Fadil F, et al. Selection of cholesterol absorption inhibitors devoid of secondary intestinal effects. Reprod Nutr Dev. 1997;37(6):691-707.

11. Muralidhara, Narasimhamurthy K, Viswanatha S, et al. Acute and subchronic toxicity assessment of debitterized fenugreed powder in the mouse and rat. Food Chem. 1999;37(8):831-838.

12. Shanmugasundaram KR, Panneerselvam C, Sumudram P, et al. Enzyme changes and glucose utilization in diabetic rabbits the effect of Gymnema sylvestre. J Ethnopharmacol. 1983;7(2):205-234.

13. Ogawa Y, Sekita K, Umemura T, et al. Gymnema sylvestre leaf extract: a 52-week dietary toxicity study in Wistar rats. Shokuhin Eiseigaku Zasshi. 2004;45(1):8-18.

14. Yokozawa T, Cho EJ, Sasaki S. The protective role of Chinese prescription kangen-karyu extract on diet- induced hypercholesterolemia in rats. Biological and Pharmaceutical Bulletin. 2006;29(4):760-765. 